\title{
Asupan Seng dan Penyembuhan Luka Sirkumsisi
}

Dr. Bondan Prasetyo SpB, Msi Med.

Staf Pengajar, Fakultas Kedokteran, Universitas Muhammadiyah Semarang

\begin{abstract}
ABSTRAK
Latar Belakang: Seng merupakan salah satu mikronutrien yang penting bagi tubuh. Salah satu fungsi seng adalah mempercepat penyembuhan luka. Dari literatur, diketahui prevalensi defisiensi seng pada anak di Indonesia cukup tinggi. Hal ini disebabkan karena pola makan anak di Indonesia yang belum cukup mengandung seng sehingga tidak mampu memenuhi kebutuhan seng dalam tubuh. Sirkumsisi merupakan salah satu tindakan bedah menimbulkan luka yang cukup menganggu akivitas bahkan berisiko menimbulkan infeksi zat gizi termasuk seng. Penyembuhan luka sirkumsisi yang cepat dan tidak menimbulkan komplikasi infeksi sangat dibutuhkan supaya anak dapat segera kembali beraktivitas normal.
\end{abstract}

\section{PENDAHULUAN}

\section{Sirkumsisi}

Sunat atau khitan atau sirkumsisi (circumsion) adalah tindakan memotong atau menghilangkan sebagian atau seluruhkulit penutup depan (kulup)dari penis. Frenulum dari penisdapat juga dipotong secara bersamaan dalam prosedur yang dinamakan frenektomi. Kata sirkumsisii berasal dari bahasa latin circum(berarti memutar) dan caedere (berarti memotong)

Saat baru lahir, kulup menempelpada kepala penis, yang tampak seperti tumpukan lapisan kulit karena berlipat. Di Tengan kepalapenis terdapat tabung yang memiliki lubang kencing dan merupakan jalan keluar air seni dan mani. Walaupun hanya sedikit bukti yang juga tidak meyakinkan, namun banyak orang meyakini bahwa kulup berperan melindungi dan menjaga kelembabankepala penis, serta mengkatkan gairah seksual karena jaringan saraf tidak terputus.

Laporan yang dikeluarkan oleh Pusat Penanggulangan dan Pencegahan Penyakit di Amerika Serikat (CD) menyatakan bahwakulup cenderung meningkatkan risiko infeksiHIV, karena kulup dapat mendorong peningkatan cairan yang berpotensi sebagai jalan masuk patogen seperti HIV. Lebih lanjut lagi, dalam uji klinis, virus yang menyebabkan kanker servics, dubur, kanker penis danvulva seringkali dihubungkan dengan pria yang tidak disunat. Sementara it, penelitian kanker penis di AmerikaSerikat di tahun 1954 dan 1997, mengungkapkan sedikitnya $95 \%$ pasien tidak disunat. Sunat juga dipercaya mengurangi risiko infeksi saluran kemih.

Salah satu alasan utama yang melatar belakangi sunat adalah agama. Prosedur sunat wajib hukumnya pada agama yahudi, begitu pula di agama kristen 
dan islam. Menurut kepercayaan yahudi, Tuhan telah memerintahkan umatnya melalui Ibrahim agar seluruh kaum pria melakukan sunat. Kitab injil juga menyebutkan bahwa Yesus, yang dipercaya sebagaiPutra Tuhan, dipersembahkan rumah kudus khusus untuk prosesi sunatnya.

Diberbagai negara, sunat memiliki kombinsiantara dasar kebudayaan dan keagamaan. Contohnya, prosedur sunat diaggap sebagai tanda seorang anak lelaki memasuki masa pubertas. Hal ini seakan menjadi penjelasan mengapa dibelahan negara lain, sunat dilakukan pada anak laki- laki berusia 10 hingga 12 tahun.

Terlepas dari kepercayaan tersebt, kulup perlu diangkat karena rentan terhadap gangguan kesehatan tertentu. Kondisi ini meliputi kulup yang tidakmampu untuk menarik kembali karena terlalu ketat (fimosis) dan parafimosis, yang terjadi ketka kulup ditarikkebelakang untuk membuka seluruh bagian kepala penis, namun tidak dapat menutup kembali. Kedua kondisi ini dapat menyebabkan nyeri dan peradangan. Sunat pada pria sangat dibutuhkan, khususnya bila kulup meradangatau pasien terdiagnosis menderita kanker penis.

Orangtua dapat menentukan prosedur sunat untuk anak. Prosedur ini umumnya dilakukan saat anak lelaki masih dalam usia bayi, diutamakan antara usia 2 hingga 8 hari (8hariadallah usia sunat yang terbaik menurut kepercayaan yahudi).namun prosedur ini akanditunda apabila anak menderita gangguan kesehatan tertentu, atau bertentangan dengan anjuran dokter.pakar kesehatan cenderung setuju dengan prinsip yang menyatakan prosedur sunat lebih baik segera dilakukan setelah anak lahir, karena komplikasi dan risiko akan lebih kecil.

\section{SIRKUMSISI DAN PENYEMBUHAN LUKA}

Sirkumsisi merupakan tindakan bedah yang meninggalkan luka yang bisa cukup mengganggu bagi anak. Hal ini dikarenakan adanya rasa nyeri dan tebatasnya gerakan yang membuat anak merasa tidak nyaman. Luka sirkumsisi seharusnya sembuh dalam waktu beberapa hari, namun beberapa hal dapat menyebabkan penyembuhan luka menjadi lebih lama. Salah satu komplikasi sirkumsisi yang sering terjadi adalah infeksi. Infeksi yang disebabkan oleh bakteri bukan satu-satunya yang menyulitkan kesembuhan luka. Khususnya pada host immunocompromised, dapat terinfeksi oleh jamur, jamur, dan virus. Infeksi dan penyembuhan luka sirkumsisi yang lama juga dapat disebabkan oleh defisiensi zat gizi. vitamin A, B, C, D, kalsium, seng, magnesium, serta zat besi adalah zat gizi mikro yang dibutuhkan dalam proses penyembuhan luka. Zat gizi mikro tersebut membantu tubuh untuk meregenerasi sel dan jaringan yang rusak, menurunkan tingkat peradangan yang terjadi, menjaga sistem kekebalan tubuh tetap normal, serta menguatkan jaringan yang baru diperbaiki. Mineral seng berperan dalam memperkuat jaringan baru sementara vitamin $\mathrm{C}$ berperan dalam pembentukan 
kolagen. Banyak penelitian membuktikan bahwa seng dapat mempercepat penyembuhan luka

Percobaan pada penyembuhan luka tikus telah menunjukkan bahwa dalam 24 jam pertama setelah cedera, ada peningkatan 15\% hingga $20 \%$ kadar seng di tepi luka, dan ini meningkat hingga 30\% selama proses pengembangan jaringan dan epidermis lebih lanjut. Peningkatan kadar seng awalnya disebabkan oleh ekspresi MT yang meningkat pada keratinosit di tepi luka, makrofag, dan fibroblast dermal, sementara tahap penyembuhan luka selanjutnya dikaitkan dengan penurunan kadar seng akibat berkurangnya pembelahan sel dan pematangan bekas luka.

Studi tambahan tentang luka bedah pada tikus menunjukkan bahwa perawatan dengan zinc topikal mengurangi keparahan luka dan membantu epitelisasi. Penelitian lain menunjukkan bahwa matriks metalloproteinase (MMPs), yaitu protein yang bergantung pada seng, sangat penting dalam penyembuhan luka. Kemampuan MMPs untuk secara enzimatis memecah fragmen kolagen ditingkatkan dengan aplikasi oksida seng, dan penghambatan aktivitas MMP secara signifikan menunda penyembuhan luka.

Peran penting seng dalam penyembuhan luka ditunjukkan oleh serangkaian percobaan di mana tingkat perbaikan luka bedah diperiksa pada tikus dengan defisiensi zinc yang diinduksi atau herediter. Sementara tikus yang diberi suplemen zinc telah menunjukkan perbaikan luka bedah, tikus dengan defisiensi seng yang disebabkan oleh keturunan atau asupan gizi yang kurak memperberat penyembuhan luka bedah. Tikus yang kekurangan zinc dan diberi suplemen zinc memiliki peningkatan kadar zinc dalam luka mereka, dan penyembuhan menjadi normal. Sementara suplemen oral zinc tidak memberikan manfaat untuk tikus normozincemic, pengobatan 12 hari oksida zinc topikal bermanfaat dalam pengobatan luka pada hewan hypozincemic dan normozincemic.

Para peneliti telah mempelajari lebih lanjut peran oksida seng dalam penyembuhan luka melalui penggunaan babi peliharaan. Pada babi normozincemic, aplikasi zinc oksida topikal menghasilkan 30\% peningkatani penyembuhan pada luka parsial Berbeda dengan zinc oxide, zinc sulfate topikal tidak memberikan manfaat untuk penyembuhan luka . Bahkan, penerapan kadar sulfat seng yang lebih tinggi (> $15 \mathrm{mmol} / \mathrm{L}$ ) secara signifikan mengganggu epitelisasi dan menginduksi respon inflamasi dermal.

Wilkinson dan Hawke melakukan tinjauan literatur sistematis menggunakan data dari Cochrane Wound Group untuk menyelidiki apakah suplementasi zinc oral bermanfaat dalam penyembuhan ulkus kaki kronis. Mereka melakukan uji 
coba terkontrol secara acak dan uji klinis terkontrol yang melibatkan penggunaan seng untuk pengobatan ulkus tungkai. Namun saying hasilnya belum memuaskan. Para penulis menyarankan perlunya pemeriksaan yang lebih menyeluruh untuk menentukan apakah suplementasi zinc sulfat oral bermanfaat pada pasien dengan defisiensi zinc.

Penelitian lain menunjukkan manfaat suplementasi zinc oral pada pasien yang kekurangan zinc dan normal. Agren melaporkan percobaan double-blind dari 37 pasien dengan ulkus tungkai dan kadar seng serum rendah di mana pasien yang menerima zinc oksida topikal telah terjadi peningkatan penyembuhan luka, peningkatan reepitelisasi, penurunan tingkat infeksi, dan penurunan tingkat kerusakan ulkus dibandingkan dengan pasien yang tidak menerima zinc oksida topikal.

Penelitian di Indonesia mencoba membuat salep luka dari ekstrak ikan gabus. Ekstrak ikan Gabus (Channa striata) terdiri dari fase air yang mengandung albumin dan fase minyak yang mengandung asam lemak omega-3 dan omega-6 yang dapat mempercepat proses penyembuhan luka. Penelitian ini bertujuan untuk mengetahui efektivitas sediaan salep yang mengandung ekstrak ikan gabus pada proses penyembuhan luka pada tikus jantan galur wistar yang diberikan secara topikal pada 6 kelompok. Pada kulit tikus dibuat luka akut stadium II terbuka, kemudian luka tersebut diolesi dengan sediaan salep dan proses penyembuhannya diamati selama 16 hari. Luas area luka diamati dengan program Macbiophotonic Image J. Persentase penyembuhan luka dihitung berdasarkan luas area lukanya dan dilanjutkan perhitungan nilai AUC. Hasil nilai AUC tiap kelompok dari terkecil hingga terbesar adalah kelompok normal $(702,84 \% \mathrm{x}$ hari), negatif $(749,56 \% \mathrm{x}$ hari), positif $(765.146 \% \mathrm{x}$ hari $)$, salep yang mengandung fase air ekstrak ikan gabus $10 \%$ (795,146\% x hari), salep yang mengandung fase minyak ekstrak ikan gabus $10 \%$ (837.282 \% x hari), dan salep kombinasi fase air-minyak ekstrak ikan gabus $10 \%(874,901 \%$ x hari). Hasil analisis menunjukkan adanya perbedaan signifikan $(\mathrm{p}<0,05)$ antara kelompok perlakuan dengan kelompok kontrol negatif.

\section{DAFTAR PUSTAKA}

1. Lansdown AB, Sampson B, Rowe A. Sequential changes in trace metal, metallothionein and calmodulin concentrations in healing skin wounds. J Anat. 1999; 195(Pt 3): 375-386.

2. Agren MS, Franzén L. Influence of zinc deficiency on breaking strength of 3week-old skin incisions in the rat. Acta Chir Scand. 1990;156(10):667-670.

3. Lansdown AB, Mirastschijski U, Stubbs N, Scanlon E, Agren MS. Zinc in wound healing: theoretical, experimental, and clinical aspects. Wound Repair Regen. 2007;15(1):2-16. 
4. Keefer K, Iocono J, Ehrlich H. Zinc-containing wound dressings encourage autolytic debridement of dermal burns. Wounds. 1998;10(2):54-58.

5. Lansdown AB. Influence of zinc oxide in the closure of open skin wounds. Int $\mathbf{J}$ Cosmet Sci. 1993;15(2):83-85.

6. Agren MS. Zinc oxide increases degradation of collagen in necrotic wound tissue. Br J Dermatol. 1993;129(2): 221-222.

7. Mirastschijski U, Haaksma CJ, Tomasek JJ, Agren MS. Matrix metalloproteinase inhibitor GM 6001 attenuates keratinocyte migration, contraction and myofibroblast formation in skin wounds. Exp Cell Res. 2004;299(2):465-475.

8. Sandstead HH, Lanier VC Jr, Shephard GH, Gillespie DD. Zinc and wound healing. Effects of zinc deficiency and zinc supplementation. Am J Clin Nutr. 1970;23(5):514- 519.

9. Hallmans G, Lasek J. The effect of topical zinc absorption from wounds on growth and the wound healing process in zinc-deficient rats. Scand J Plast Reconstr Surg. 1985;19(2):119-125.

10. Agren MS, Chvapil M, Franzen L. Enhancement of re-epithelialization with topical zinc oxide in porcine partialthickness wounds. J Surg Res. 1991;50(2):101-105.

11. Agren MS. Zinc in wound repair. Arch Dermatol. 1999; 135(10):1273- 1274.

12. Tarnow P, Agren M, Steenfos H, Jansson JO. Topical zinc oxide treatment increases endogenous gene expression of insulin-like growth factor-1 in granulation tissue from porcine wounds. Scand J Plast Reconstr Surg Hand Surg. 1994;28(4):255-259.

13. Shenkin A. Trace elements and inflammatory response: implications for nutritional support. Nutrition. 1995;11 (1 Suppl):100-105.

14. Gaetke LM, McClain CJ, Talwalkar RT, Shedlofsky SI. Effects of endotoxin on zinc metabolism in human volunteers. Am J Physiol. 1997;272(6 Pt 1):E952E956.

15. Henzel JH, DeWeese MS, Lichti EL. Zinc concentrations within healing wounds. Significance of postoperative zincuria on availability and requirements during tissue repair. Arch Surg. 1970;100(4):349-357. 42. Philcox JC, Coyle P, Michalska A, Choo KH, Rofe AM. Endotoxin-induced inflammation does not cause hepatic zinc accumulation in mice lacking metallothionein gene expression. Biochem J. 1995;308(Pt 2):543-546.

16. Wilkinson EA, Hawke CI. Does oral zinc aid the healing of chronic leg ulcers? A systematic literature review. Arch Dermatol. 1998;134(12):1556-1560. 44. Agren MS. Studies on zinc in wound healing. Acta Derm Venereol Suppl (Stockh). 1990;154:1-36.

17. Agren MS, Stromberg HE. Topical treatment of pressure ulcers. A randomized comparative trial of Varidase and zinc oxide. Scand J Plast Reconstr Surg. 1985;19(1):97-100.

18. Apelqvist J, Larsson J, Stenström A. Topical treatment of necrotic foot ulcers in diabetic patients: a comparative trial of DuoDerm and MeZinc. Br J Dermatol. 1990;123(6):787-792.

19. Gang RK. Adhesive zinc tape in burns: results of a clinical trial. Burns. 1981;7(5):322-325.

20. Berger MM, Cavadini C, Bart A, et al. Cutaneous copper and zinc losses in burns. Burns. 1992 
21. Mohamad Andrie1, Dies Sihombing. Efektivitas Sediaan Salep yang Mengandung Ekstrak Ikan Gabus (Channa striata) pada Proses Penyembuhan Luka Akut Stadium II Terbuka pada Tikus Jantan Galur Wistar. Pharm Sci Res ISSN 24072354 